УДК 618.3-06:618.15-022.7]-07-085

DOI

\author{
๑ В. Ф. Нагорна, Т. Я. Москаленко, А. А. Гриценко
}

Одесъкий національний медичний університет

\title{
ДІАГНОСТИЧНА ІНФОРМАТИВНІСТЬ ПОКАЗНИКА рН ПІХВОВОГО ВМІСТУ У ХВОРИХ НА ВАГІНАЛЬНІ ІНФЕКЦІї
}

ДІАГНОСТИЧНА ІНФОРМАТИВНІСТЬ ПОКАЗНИКА РН ПІХВОВОГО ВМІСТУ У ХВОРИХ НА ВАГІНАЛЬНІ ІНФЕКЦІЇ. На підставі обстеження (цитологічний, рН-метрія піхвового вмісту, бактеріологічний, ДНК-технології, ІФА рівня естрогенів) 30 жінок віком 23-42 років виявлено високий кореляційний зв'язок між показником рН піхвового секрету, рівнем естрадіолу та кількістю лактобактерій у піхвовому біотопі, низьку інформативність показника кількості лейкоцитів у піхвовому мазку.

ДИАГНОСТИЧЕСКАЯ ИНФОРМАТИВНОСТЬ ПОКАЗАТЕЛЯ РН ВЛАГАЛИЩНОГО СОДЕРЖИМОГО У БОЛЬНЫХ С ВАГИНАЛЬНЫМИ ИНФЕКЦИЯМИ. На основании обследования (цитологический, рН-метрия влагалищного содержимого, бактериологический, ДНК-технологий, ИФА уровня эстрогенов) 30 женщин в возрасте 23-42 лет обнаружено высокую коррелятивную связь между показателем рН влагалищного секрета, уровнем эстрадиола и количеством лактобактерий в биотопе, низкую информативность количества лейкоцитов во влагалищном мазке.

DIAGNOSTIC INFORMATIVENESS OF pH-INDICATOR OF VAGINAL CONTENTS IN PATIENTS WITH VAGINAL INFECTIONS. Authors on the basis of examination (cytological, pH-test of vaginal secretions, bacteriological, DNA technology, IFA estrogen levels) of 30 women aged 23-42 years found a high correlative relationship between $\mathrm{pH}$ value of vaginal content of estradiol levels and the number of lactobacilli in vaginal biotope, low information content of the index number of leukocytes in the vaginal smear .

Ключові слова: вагінальні інфекції, рН піхвового вмісту, естрадіол, лактобактерії.

Ключевые слова: вагинальные инфекции, рН вагинального содержимого, эстрадиол, лактобактерии.

Key words: vaginal infections, $\mathrm{pH}$ of the vaginal contents, estradiol, lactobacilli.

ВСТУП. На сьогодні основним джерелом інфікування статевих шляхів і плода під час вагітності, в післяпологовому періоді та висхідної інорекції в гінекологічній практиці вважається ендогенна інорекція самої хворої. Осередками такої інфекції можуть бути різні органи сечовидільної системи, дихальної, вухо-горло-ніс, кишечник, але частіше за інші роль такого осередку виконує піхва та цервікальний канал. Ендогенна фрлора піхви вивчається десятиріччями, але тільки в останні роки склалось уявлення про піхвову екосистему як про біоценоз окремого органа 3 дуже поліморфною непостійною фрлорою, що змінюється в різні вікові періоди, навіть в різні фрази менструального циклу, під час вагітності та в різні дні після пологового періоду [1]. На якісний та кількісний її склад впливають спосіб життя, екстрагенітальна інсекція та патологія, особливості інтимної гігієни та сексуальних стосунків, білизни та інші фрактори, серед яких ні лікар, ні пацієнтка не завжди можуть ідентифрікувати саме той, що $є$ головним.

Мінливість мікробного складу біоценозу піхви призводить інколи до неправильного трактування результатів мікробіологічного дослідження, коли «нормі» привласнюється клінічний діагноз, що тягне за собою агресивну санацію піхви, системну антибіотикотерапію з наступним імуносупресивним есректом, кандидозом. Неправильне трактування аналізів та нераціональна тактика лікаря перетворюють медичну проблему на соціальну. В останні роки мінливій «нормі» на основі багаточисельних досліджень були визначені більш-менш чіткі межі. Так, серед аеробів облігатних та фракультативних (Гр (+) - стафрілокок епідермальний, стрептокок, у тому числі В - гемолітичний; Гр (-) палички E. coli, клебсієла, ентерококи та інші) переважають лактобактерії до 88-100 \% .
Кількість лактобактерій у піхвовому секреті, а саме їх зменшення, визначають перехід від нормоценозу до запальної патології. У ланцюгу тісно пов'язаних між собою причинно-наслідкових фракторів від фрункції яєчників до рівня кислотності піхвового секрету роль лактобацил у змінах біоценозу найбільш визначена [1].

Група анаеробів представлена гарднерелою, атопобіум, превотелою та ін. I ті та інші можуть бути присутніми так саме, як і дріжджі, мікоплазми в концентрації, що не перевищує $10^{3}$. Недопустима наявність у піхві збудників ІПСШ [1].

Мінливість біоценозу піхви найнебезпечніша під час вагітності. Існуючі нормативні документи зобов'язують лікаря, який спостерігає вагітну, виконати діагностику інфекцій в ранні терміни і при позитивних результатах не повторювати їі. Але добре відомо, що інфрікування статевих шляхів можливе в будь-які терміни вагітності і перед пологами.

Такий статус багатогранної проблеми вагінальних інфекцій потребує пошуку адекватних, доступних, легких в інтерпретації методів діагностики. Тому привертає увагу метод рН-метрії піхвового вмісту.

МАТЕРІАЛИ ТА МЕТОДИ. Досліджувану групу склали 30 жінок репродуктивного та пізнього репродуктивного віку від 23 до 42 років, 10 із них звернулись для профрілактичного огляду, вони вважали себе здоровими. У 6 жінок були скарги на порушення репродуктивної фрункції (вторинне непліддя) 3 порушенням менструальної функції (в одної - вторинна аменорея, у 3-х - рідкі місячні, в 2-х у віці 37 та 42 роки - аномальні маткові кровотечі), крім означених скарг ці жінки вказували на дискомфорт, свербіж та печію у піхві, патологічні виділення. Інші 14 жінок звернулись з приводу патологічних виділень із піх- 
ви, 19 жінок приймали КОК. У 26 жінок в анамнезі були неускладнені пологи, в однієї з підгрупи з порушенням менструального циклу - позаматкова вагітність із наступною тубектомією, у другої з цієї підгрупи - видалення яєчника з приводу доброякісної пухлини. Одна 3 жінок спостерігалась 3 приводу виснаження фрунції яєчників (ФСГ 31,9 мМО/мл, ЛГ 23,9 мМО/мл). Особливості загальносоматичного анамнезу: 25 жінок вважали себе здоровими, але при опитуванні з'ясувалось, що у 19 з них були клінічні ознаки дисфункції кишечника (закрепи, періодичний біль), у 4-х - хронічний пієлонефрит, у 7-ми - пародонтоз. 3 дослідження виключені хворі на TORCHінфрекції в гострій стадії.

У роботі використані методи дослідження: загальноклінічні (анамнез, скарги, гінекологічний огляд із фріксацією уваги на характер виділень, колір шкіри та слизових оболонок, рухливість слизової, характер судинного малюнка на ектоцервіксі, навколо зовнішнього вічка); лабораторні методи (цитологічний метод дослідження мазка, бактеріологічний, із визначенням відсоткового вмісту лактобактерій та інших мікробів); ІФА та ПЛР для виявлення ІПСШ; методи з використанням ДНК-технології, 3 визначенням загальної бактеріальної маси та кількісного вмісту лактобактерій, аеробних та анаеробних збудників, грибів, мікоплазм; рН-метрія піхвового вмісту за допомогою тест-смужок; ІФА метод визначення естрадіолу; статистичні.

Стан біоценозу за даними мікроскопії оцінювали наступним чином $[1,4]$ : нормоценоз - домінування лактобактерій, відсутність Гр (-) фрлори, спор, міцелію, псевдогіфрів, поодинокі лейкоцити та клітини поверхневого епітелію. Проміжний тип - кількість лактобактерій помірно знижена, наявні Гр (+) коки та Гр (-) палички, збільшена кількість лейкоцитів, є моноцити, макрофаги, клітини поверхневого епітелію. Дисбіоз піхви (бактеріальний вагіноз) - кількість лактобактерій різко знижена або вони відсутні, різке збільшення загальної кількості бактерій із домінуванням аеробів (гарднерела), наявність «ключових клітин», відсутність або поодинокі лейкоцити, незавершеність фагоцитозу. Аеробний вагініт - велика кількість лейкоцитів, Гр (-) та Гр (+) фрлора умовно- та патогенна фрлора, макрофраги, фрагоцитоз.

РЕЗУЛЬТАТИ ДОСЛІДЖЕННЯ ТА ЇХ ОБГОВОРЕННЯ. Для аналізу та пошуку корелятивних зв'язків між показниками основних захисних механізмів слизової піхви (рівень естрогенів та кількість лактобацил) досліджувана група за значенням рН була розподілена на 4 підрупи: $\mathrm{I}-\mathrm{pH} 4,0-4,4(\mathrm{n}=5)$; II - pH 4,7 (n=10); III - pH 5,0 (n=6); IV - pH>5,0-5,5-7,0 (n=9). Жінки були обстежені В I і II фразах циклу. В I підгрупі (рН 4,0-4,4) рівень естрадіолу в I і II фразах коливається в межах 75,4-90,2 пг/мл, у однієї з передчасним виснаженням яєчників 21,3 пг/мл. У ІІ підгрупі (рH 4,4-4,7) рівень естрадіолу виявлено в межах у I фразі 75,4-95,2 пг/мл, у II фразі - 102,4-211,3 пг/мл, у однієї він був низьким. У жінок III-IV груп із рH 5,0 та вище рівень естрадіолу в 12 із 15 жінок був 52,4-42 пг/мл, у трьох - 114-186,5 пг/мл. Пошук кореляційних зв'язків проведено в кластерах із найбільшим скупченням цифр. Індекс кореляції Спірмана в 4 підгрупах був r=-0,63, що свідчить про високий кореляційний зв'язок між двома показниками - маркерами фрункції яєчників та стану мікробіоти піхви.
Аналіз показника рН та даних мікробіологічного стану піхви за даними методів ДНК-технологій показав, що відсоток лактобактерій у піхвовому біотопі в I-II підгрупах із рН до 4,4 відповідає значенням 100-78 \% $(\log 7,3-8,4)$ від загальної бактеріальної маси. При рН 4,7 він знижувався до 57-41 \%, а при рН 5,0-5,5-7,0 (log 4,5-3,4-2,0) він був дуже низьким. Констатовано високий зворотний кореляційний зв'язок між показником рН піхвового вмісту та кількісним вмістом лактобацил у ньому (індекс Спірмана $r=-0,95)$.

Аналіз типу піхвових мазків за кількістю лейкоцитів та характером мікрофрлори показав, що значення $\mathrm{pH}$ 4,0-4,4 відповідають нормоценозу та проміжковому типу біоценозу. Але в цій групі у 3 жінок були ідентифріковані Candida alb. $10^{4}-10^{5}$. В жодному випадку в цій групі не виявлені гарднерели, атопобіум, мікоплазми. У II групі $3 \mathrm{pH}$ 4,7 в мазках була різноманітна картина з кількістю лейкоцитів 0-3-4-10 у п/3 та різноманітною фрлорою в бактеріологічних відповідях (гарднерела, атопобіум у значній кількості) та патогенні, умовно-патогенні збудники в незначній кількості, що давало підстави для діагнозу бактеріальний вагіноз. При $\mathrm{pH}>5-5,5-7,0$, зазвичай, у мазках кількість лейкоцитів варіювала від 0 до 80, виявлена при відсутності або різкому зниженні паличкової фрлори (лактобацил), превалювала фрлора кокова, при бактеріологічному дослідженні - ентерококи, стасрілострептококи, мікоплазми, гарднерели, що дозволяло ставити діагноз аеробний вагініт або змішаний вагініт.

Варто зазначити, що лейкоцити в мазках (показник, на який, зазвичай, орієнтується практичний лікар) не корелюють з кількісним чи якісним вмістом мікрофрлори.

Таким чином, отримані результати дозволяють вважати, що серед існуючих методів дослідження (цитологічний, бактеріологічний, ДНК-технології, ПЛР), характеру піхвового біотопу визначення рН піхвового вмісту може і повинно виконуватись при обстеженні пацієнток, які звернулись до гінеколога. Показник дозволяє визначити характер біоценозу піхви до проведення інших більш затратних за часом та фрінансами методів, або в їх відсутності, особливо в амбулаторних умовах. Простота та неінвазивність, швидкість визначення дозволяють використовувати його як скринінговий або для моніторингу стану слизової піхви у віддалені періоди після лікування. Метод більш інформативний, ніж цитологічний.

Виявлений високий кореляційний зв'язок із рівнем естрадіолу дозволяє опосередковано оцінювати фрункцію яєчників, а висока кореляція з кількістю лактобацил свідчить, що саме вони забезпечують кисле середовище піхви. Загальновизначена практика оцінки стану біоценозу за вмістом лейкоцитів не завжди відображає стан біоценозу піхви. Показник рН піхвового вмісту може бути інтегральним показником стану репродуктивної системи і тому потребує пошуку кореляційних зв'язків з іншими показниками цієї системи.

ВИСНОВкИ. 1. Показник рН піхвового вмісту має зворотний кореляційний зв'язок із показником рівня естрадіолу.

2. Показник рН піхвового вмісту має зворотний кореляційний зв'язок із показником вмісту лактобактерій у піхвовому біотопі.

3. Кількість лейкоцитів у піхвових мазках не відповідає бактеріологічній характеристиці біотопу. 
4. $\mathrm{pH}$-метрія піхвового секрету є інфрормативним, простим, неінвазивним методом діагностики вагінальних інсрекцій.

\section{СПИСОК ЛІТЕРАТУРИ}

1. Радзинский В. Е. Акушерская агрессия / В. Е. Радзинский. - М. : Изд-во журнала Status praesens, 2012. - 672 с.

2. Батырова 3. К. Оценка кислотно-щелочного баланса слизистой оболочки влагалища у девочек-подростков: диагностические возможности / З. К. Батырова, Д. А. Кругляк // Акушерство и гинекология. - 2014. - № 4 (45). - С. 20-22.

3. Некоторые аспекты определения эффрективности терапии дисбиоза влагалища в клинических условиях /
ПЕРСПЕКТИВИ ПОДАЛЬШИХ ДОСЛІДЖЕНЬ. ВИвчення рН піхвового вмісту може використовуватись як скринінг для своєчасного виявлення піхвової інфекції та попередження деяких ускладнень гормонального та інфрекційного характеру.

Ф. Ф. Бадретдинова, А. Р. Мавзютов, Л. А. Шейда, Ф. А. Каюмов // Практическая медицина. - 2009. - № 3. - С. 31-34.

4. Кира Е. Ф. Клиника и диагностика бактериального вагиноза / Е. Ф. Кира // Акушерство и гинекология. - 1996. - № 2. - C. 32-35.

5. Guaschino S. SOPHY project: an observational study of vaginal $\mathrm{pH}$ and lifestyle in women of different ages and in different physiopatological conditions / S. Guaschino, C. Benvenuti // Minerva Ginecol. - 2008. - Vol. 60 (2). - P. 105-114.

Отримано 11.02 .16 